


\section{COLONIAL GENOCIDE IN}

\section{INDIGENOUS NORTH AMERICA}

ANDREW WOOLFORD, JEFF BENVENUTO, and ALEXANDER LABAN HINTON, editors

Foreword by Theodore Fontaine

DUKE UNIVERSITY PRESS | DURHAM AND LONDON 2014 
() 2014 Duke University Press

All rights reserved

Printed in the United States of America on acid-free paper $\infty$

Designed by Barbara E. Williams

Typeset in Garamond Premier Pro and DIN Engschrift I 45I by BW\&A Books, Inc.

Cover art: Daphne Odjig, Genocide No. I, 1971. Permission of Stan Somerville.

Library of Congress Cataloging-in-Publication Data

Colonial genocide in indigenous North America / Andrew Woolford, Jeff Benvenuto, and Alexander Laban Hinton, editors ; foreword by Theodore Fontaine.

pages $\mathrm{cm}$

Includes bibliographical references and index.

ISBN 978-0-8223-5763-6 (cloth : alk. paper)

ISBN 978-0-8223-5779-7 (pbk. : alk. paper)

I. Indians of North America-Colonization.

2. Genocide-North America-History.

3. Off-reservation boarding schools-History.

I. Woolford, Andrew John, I97I-

II. Benvenuto, Jeff, I984-

III. Hinton, Alexander Laban.

E77.C 692014

$970.004^{\prime} 97-\mathrm{dc} 23$

2014020685

Duke University Press gratefully acknowledges the support of the Social Sciences and Humanities Research Council of Canada, which provided funds toward the publication of this book. 